\title{
Heavy Metals in Lipstick Products Marketed in Saudi Arabia
}

\author{
Faten M. Ali Zainy \\ Department of Chemistry, Faculty of Sciences, King Abdulaziz University, Jeddah, Kingdom of Saudi Arabia \\ Email: fzainalabdeen@kau.edu.sa
}

How to cite this paper: Zainy, F.M.A. (2017) Heavy Metals in Lipstick Products Marketed in Saudi Arabia. Journal of Cosmetics, Dermatological Sciences and Applications, 7, 336-348.

https://doi.org/10.4236/jcdsa.2017.74030

Received: October 10, 2017

Accepted: December 18, 2017

Published: December 21, 2017

Copyright $\odot 2017$ by author and Scientific Research Publishing Inc. This work is licensed under the Creative Commons Attribution-NonCommercial International License (CC BY-NC 4.0). http://creativecommons.org/licenses/by-nc/4.0/

\begin{abstract}
The present study reports the content of 14 heavy metals (Al, Fe, Ti, Ag, As, $\mathrm{Ba}, \mathrm{Cd}, \mathrm{Co}, \mathrm{Cr}, \mathrm{Cu}, \mathrm{Mn}, \mathrm{Ni}, \mathrm{Pb}$, and $\mathrm{Zn})$ in twenty-two $(\mathrm{n}=22)$ lipstick products of imported and locally manufactured at the local market in Jeddah, Saudi Arabia using Inductivity Coupled Plasma-Optical Emission Spectrophotometer (ICP-OES). The overall average contents of $\mathrm{Al}, \mathrm{Fe}, \mathrm{Ti}, \mathrm{Ag}, \mathrm{As}, \mathrm{Ba}, \mathrm{Cd}$, $\mathrm{Co}, \mathrm{Cr}, \mathrm{Cu}, \mathrm{Mn}, \mathrm{Ni}, \mathrm{Pb}$, and $\mathrm{Zn}$ were $3131.18 \pm 0.09,9642.92 \pm 0.079,46.59 \pm$ $0.109,0.545 \pm 0.009,2.041 \pm 0.024,1371.439 \pm 0.085,0.134 \pm 0.008,4.242 \pm$ $0.02, \mathrm{ND}, 3.934 \pm 0.03,19.712 \pm 0.012,20.196 \pm 0.056,0.725 \pm 0.012$, and $858.666 \pm 0.083 \mu \mathrm{g} / \mathrm{g}$, respectively. The correction coefficient of the results is up to 0.9995 , showing an excellent linear relationship between metal concentrations in samples. The results also revealed that, the total concentrations of toxic metals in various samples ranged from $1201.35-60,800.36 \mu \mathrm{g} / \mathrm{g}$. The dark-colored lipstick samples $1 \mathrm{~B}, 2 \mathrm{~B}, 3 \mathrm{~B}, 4 \mathrm{~B}, 5 \mathrm{~B}, 7 \mathrm{~B}, \mathrm{~B} 8,9 \mathrm{~B}$, and 10B revealed high content of total toxic metals compared to the light-colored lipstick samples $1 \mathrm{~A}, 2 \mathrm{~A}, 3 \mathrm{~A}, 4 \mathrm{~A}, 4 \mathrm{C}, 5 \mathrm{~A}, 7 \mathrm{~A}, 8 \mathrm{~A}, 9 \mathrm{~A}$, and 10A. The concentrations of $\mathrm{Al}$, $\mathrm{Fe}, \mathrm{Ba}$, and $\mathrm{Zn}$ in the samples within each class under investigation are relatively high whereas the concentrations of $\mathrm{Ag}, \mathrm{As}, \mathrm{Cd}, \mathrm{Co}, \mathrm{Cu}$, and $\mathrm{Pb}$ are lowest; and $\mathrm{Ti}, \mathrm{Mn}$, and $\mathrm{Ni}$ contents were below $100 \mu \mathrm{g} / \mathrm{g}$. Chromium was not detected in any sample. Since no safe limits for most of these metals relating to cosmetic products are available in Saudi Arabia, it is hard to ascertain whether the values obtained in this study are relatively high or low. Prolonged use of products containing these elements may pose a threat to human health and could damage the environment.
\end{abstract}

\section{Keywords}

Lipstick, Heavy Metals, Inductivity Coupled Plasma-Optical Emission Spectrometry (ICP-OES) 


\section{Introduction}

Since the dawn of civilization, cosmetic products have been considered a part of routine body care [1] [2]. During the past few decades, The use of these products including care creams, talcum and face powders, lipstick, kajal, sindoor, eye makeup, and mouthwash has increased markedly in the last few decades [2] [3]. Dermal exposure is considered the most significant concern because most cosmetic products are direct practice to the skin. Oral exposure can also occur when cosmetics containing heavy metal tarnishes are applied around the mouth and from hand-to-mouth contact [4]. Heavy metals are incorporated into these products for functional reasons. Thus, for instance, the main ingredients of press powder for eye shadow are talc and pigments, with zinc or magnesium stearate used as a binding agent. A brilliant metallic finish is created with copper, aluminum, brass, gold, or silver powders. Heavy metals, such as cadmium, copper, and lead, remain as tarnishes in the pigments used in eye shadows or are released by the machinery used during the industrializing process [5].

Lead, cadmium, mercury, chromium, nickel, and copper are the most common heavy metals detected in cosmetic products, including shampoo, lipstick, cream, eye shadow and powder [5]. The ingredients and colorants, along with inadequate purification of raw materials, contribute to the presence of these impurities in cosmetics [6]. Cosmetics appear on the list of products manufactured in various parts of the world for which recall notices have been issued in the US. Thus, in Caribbean countries, an import alert was declared for skin-whitening cream after Hg level in the product measure 8\% [7].

Regarding the potential adverse effects of heavy metal $(\mathrm{Pb}, \mathrm{Cd}, \mathrm{Hg})$ contamination, the widespread availability and use of cosmetic products has attracted the attention of researchers and clinicians [8] [9] [10]. The fact that, when heavy metal ions come into contact with the human body, they are absorbed and form complexes with the carboxylic acids $(-\mathrm{COOH})$, amines $\left(-\mathrm{NH}_{2}\right)$, and thiols $(-\mathrm{SH})$ of proteins, results in cell damage, death and/or leads to a variety of diseases. Treatment for metal intoxication usually involves a chelating agent that binds with the metal ions to form complexes that are then removed from the body [11]. Some cosmetics have been implicated in such harmful effects as cancer, allergic reactions, mutations, respiratory distress, and developmental and reproductive problems [12]. Elevated levels of $\mathrm{Cd}$ have been reported to interfere with DNA replication and zinc causing symptoms that mimic those of lead poisoning [13]. Table 1 summarizes the poisoning effect of selected heavy metals in the form of various diseases when ingested or inhaled [9].

The absorption of toxic metals through dermal contact is scanty, thus little data are known regarding personal care products [14]. Arecent literature survey has been conducted in 2004 in US on the use of lipstick [15]. Over $63 \%$ of girls aged 7 - 19 were used this product. Lipstick is ingested when the lips are licked during eating, drinking, or kissing, thus it is said that "women without intention eat about $4 \mathrm{lb}$ of lipsticks in a lifetime" [15]. Few current international standards 
Table 1. Recommended limits and toxicity for some metals.

\begin{tabular}{|c|c|c|c|c|c|c|c|c|c|c|c|c|c|c|c|}
\hline Element & $\mathrm{Al}$ & $\mathrm{Fe}$ & $\mathrm{Ti}$ & $\mathrm{Ag}$ & As & $\mathrm{Ba}$ & $\mathrm{Cd}$ & Co & $\mathrm{Cr}$ & $\mathrm{Cu}$ & $\mathrm{Mn}$ & $\mathrm{Ni}$ & $\mathrm{Pb}$ & $\mathrm{Zn}$ & Refs. \\
\hline \multirow{6}{*}{ 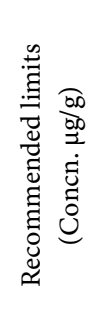 } & - & - & - & - & 3 & - & 3 & - & - & - & - & - & 10 & - & [16] \\
\hline & - & - & - & - & - & - & 5 & - & - & - & - & - & 20 & - & [2] \\
\hline & - & - & - & - & - & - & banned & banned & banned & - & - & banned & banned & - & [18] \\
\hline & & & As & & & & & & & & & & & & \\
\hline & - & - & $\begin{array}{l}\mathrm{TiO}_{2} \\
25 \%\end{array}$ & - & banned & anned & banned & - & banned & - & - & - & banned & - & [19] \\
\hline & - & - & - & - & - & - & - & 170 & 170 & - & - & 170 & 20 & - & [17] \\
\hline 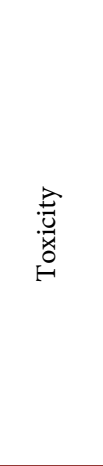 & & 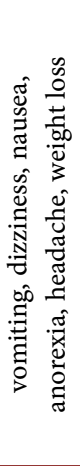 & & &  & & 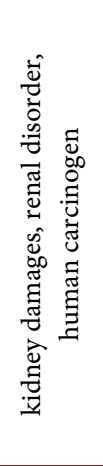 & 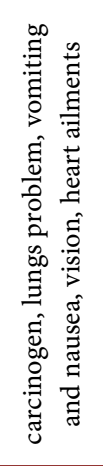 & 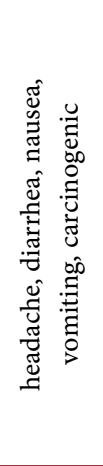 & 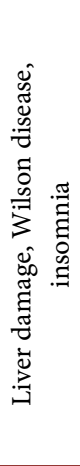 & & 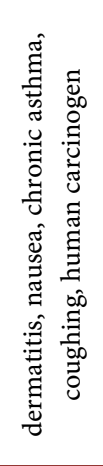 & 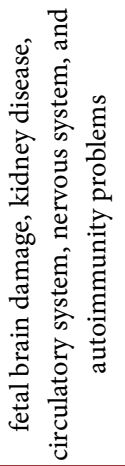 & 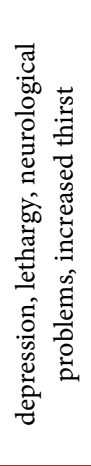 & {$[10][23]$} \\
\hline
\end{tabular}

are for heavy metal impurities in cosmetics, apart from limits of $20 \mu \mathrm{g} / \mathrm{g} \mathrm{Pb}$ and $5 \mu \mathrm{g} / \mathrm{g}$ for Cd [2]. The Canadian government has imposed limits for certain metals in cosmetics: $10 \mu \mathrm{g} / \mathrm{g}$ for Pb, $3 \mu \mathrm{g} / \mathrm{g}$ for As, Cd and $\mathrm{Hg}$, and $5 \mu \mathrm{g} / \mathrm{g}$ for Sb [16]. The levels of $\mathrm{Ni}, \mathrm{Cr}$, and Co should not exceed $170 \mu \mathrm{g} / \mathrm{g}^{-1}$ whereas $\mathrm{Pb}$ should be within $20 \mu \mathrm{g} / \mathrm{g}^{-1}$ [17]. The European Union (EU) has also bump up a list of more than 1000 compounds that are not permitted from use in cosmetic manufacturing [7]. On the other hand, Directive 76/768/EEC has banned the use of Cd, Co, $\mathrm{Cr}, \mathrm{Ni}$, and $\mathrm{Pb}$ in the cosmetics preparation [18].

The Saudi Standards, Metrology, and Quality Organization (SASO//1953/ 2005) have banned many metals, including arsenic compounds, barium and its salts, $\mathrm{Be}, \mathrm{Cd}$ and their compounds, $\mathrm{Cr}$, Au salts, phosphorus compounds, potassium cyanide, iodine, lead and its compounds, and compounds containing strontium and selenium, and placed limits on titanium oxide [19]. Thus, the overall goals of the present study are focused on: 1) Ascertaining the concentrations of heavy metals in various local and imported cosmetics; 2) Helping the consumers in seeking more healthy alternatives to products that contain these impurities and finally; 3 ) producers that will bring to market cosmetics that do not compromise human health under optimized conditions.

\section{Materials and Methods}

\subsection{Sample Collection}

Samples of usually used lipstick products were bought from local markets in the Albald district in the city of Jeddah, KSA. Twenty-two lipstick samples of imported (from developed and developing countries) and manufactured locally (by 
unauthorized national companies with little or no quality control measures) at the local market in Jeddah, Saudi Arabia were collected. The prices of the lipstick samples ranging in price from $\$ 0.53$ to $\$ 52$ USD per container (Table 2). The samples were assorted and grouped according to price: lower class ( $\$ 0.53$ $\$ 13.33)$, middle class (\$33.33 - \$17.33), and higher class (\$48 - \$52). The samples were also assorted as either light in color (A and C: pink, pink ice, pink chiffon, rosette, French pink, green, deep color, baby doll, shine beige, pimpante, and rose) or dark in color (B: russet, brown, chocolate, black, cutting edge, bright red, matt brown, priate, and red). All of the samples (Table 2) were transferred to the laboratory heavy metal analysis.

\subsection{Reagents and Standards}

High purity nitric acid (65\%, Sigma Aldrich) and hydrofluoric acid (70\% - 72\%, Sigma Aldrich) were used for sample digestion. Hydrofluoric acid (HF) was neutralized after digestion by few drops of boric acid solution (4\%) [20] [21] [22]. Calibration standards for each heavy metal were prepared daily y from the certified

Table 2. Samples collected and their prices.

\begin{tabular}{|c|c|c|c|c|}
\hline Brand Code & Sample Code & Source & Color & Price SR/\$ \\
\hline \multirow{8}{*}{ Lower class } & $\begin{array}{l}1-\mathrm{A} \\
1-\mathrm{B}\end{array}$ & USA & $\begin{array}{c}\text { pink ice } \\
\text { russet }\end{array}$ & $10 / 2.67$ \\
\hline & $\begin{array}{l}2-\mathrm{A} \\
2-\mathrm{B}\end{array}$ & Saudi Arabia & $\begin{array}{l}\text { pink } \\
\text { brown }\end{array}$ & $10 / 2.67$ \\
\hline & $\begin{array}{l}3-\mathrm{A} \\
3-\mathrm{B}\end{array}$ & USA & $\begin{array}{c}\text { pink chiffon } \\
\text { chocolate }\end{array}$ & $20 / 5.34$ \\
\hline & $4-\mathrm{A}$ & \multirow[b]{2}{*}{ Taiwan } & green & \multirow[b]{2}{*}{$2 / 0.53$} \\
\hline & $\begin{array}{l}4-\mathrm{C} \\
4-\mathrm{B}\end{array}$ & & $\begin{array}{l}\text { pink } \\
\text { black }\end{array}$ & \\
\hline & $\begin{array}{l}5-\mathrm{A} \\
5-\mathrm{B}\end{array}$ & England & $\begin{array}{c}\text { rossetto } \\
\text { cutting edge }\end{array}$ & $\begin{array}{l}35 / 9.33 \\
25 / 6.67\end{array}$ \\
\hline & $\begin{array}{l}6-\mathrm{A} \\
6-\mathrm{B}\end{array}$ & Saudi Arabia & $\begin{array}{c}\text { French pink } \\
\text { bright red }\end{array}$ & $40 / 10.67$ \\
\hline & $\begin{array}{l}7-\mathrm{A} \\
7-\mathrm{B}\end{array}$ & Italy & $\begin{array}{l}\text { matte pink } \\
\text { matte brown }\end{array}$ & $50 / 13.33$ \\
\hline \multirow[t]{2}{*}{ Middle class } & $\begin{array}{l}8-\mathrm{A} \\
8-\mathrm{B}\end{array}$ & Italy & $\begin{array}{l}\text { baby doll } \\
\text { red }\end{array}$ & $125 / 33.33$ \\
\hline & 9-A & France & shine beige & $133 / 17.33$ \\
\hline \multirow{2}{*}{ Higher class } & $\begin{array}{l}10-\mathrm{A} \\
10-\mathrm{B}\end{array}$ & France & $\begin{array}{c}\text { pimpante } \\
\text { pirate }\end{array}$ & $180 / 48$ \\
\hline & $\begin{array}{l}11-\mathrm{A} \\
11-\mathrm{B}\end{array}$ & France & $\begin{array}{l}\text { rose } \\
\text { red }\end{array}$ & $195 / 52$ \\
\hline
\end{tabular}


standard stock solution (High-Purity Standards ICP-MS-68B Solution A, 100 $\mathrm{mg} / \mathrm{L}$ in $\mathrm{HNO}_{3}(4 \%)$ in the range from 0.5 to $10 \mathrm{ppm}$. All the solutions were prepared in double distilled water. Dilution correction was applied for samples diluted or concentrated during analysis.

\subsection{Sample Preparation}

All plastic and glassware were cleaned, rinsed repeatedly with tap water, and then dipped in a $5 \% \mathrm{HNO}_{3}$ solution for a minimum of $24 \mathrm{hs}$ followed by rinsing with deionized water before use. The general sample preparation method followed previously published procedures [22].

Step 1: On a microwave vessel: put $0.3 \mathrm{~g}$ of sample, $7 \mathrm{~mL}\left(65 \% \mathrm{HNO}_{3}\right)$, and 2 $\mathrm{mL}(72 \% \mathrm{HF})$, then baked the sample over 15 minutes to $130^{\circ} \mathrm{C}$. Keep samples at $130^{\circ} \mathrm{C}$ for $3 \mathrm{~min}$. The temperature was then raised to $200^{\circ} \mathrm{C}$ for $45 \mathrm{~min}$.

Step 2: Added $30 \mathrm{~mL}$ of $4 \%$ boric acid solution to the vessels, baked samples again in the microwave to $170^{\circ} \mathrm{C}$ over 15 minutes and retained for 10 minutes at $170^{\circ} \mathrm{C}$. dilute The samples to $50 \mathrm{~mL}$ using $\mathrm{DI} \mathrm{H}_{2} \mathrm{O}$. A final $1000 \times$ dilution was accomplish prior to ICP-MS analysis. In cases where a brown color appeared, adding the mixture of concentrated acid through slow and continuous heating until white fumes appeared, continuous to dryness [13]. After cooling, the solutions were filtered through Whatmann no. 42 and transferred to a calibrated flask $(100 \mathrm{~mL})$ and completed to the mark with deionized water.

\subsection{Sample Analysis}

Precise determination of heavy metal content in cosmetic products is important because there is a narrow range between safe and toxic levels. Various methods are currently available for detecting heavy metals, including inductively coupled plasma mass spectrometry (ICP-MS) [2], inductively coupled plasma optical emission spectrometry [23] [24], sector field inductively coupled plasma mass spectrometry (SF-ICP-MS) [18] and plasmafission spectrograph [25]. A Perkin Elmer-Optima 7300DV Inductively coupled plasma-optical emission spectrometry was used for $\mathrm{Al}, \mathrm{Fe}, \mathrm{Ti}, \mathrm{Ag}, \mathrm{Ba}, \mathrm{Cd}, \mathrm{Co}, \mathrm{Cr}, \mathrm{Cu}, \mathrm{Mn}, \mathrm{Ni}, \mathrm{Pb}$, and $\mathrm{Zn}$ under the optimized parameters (Table 3) at power, $1550 \mathrm{~W}$; plasma gas, $15 \mathrm{~L} / \mathrm{min}$; aux gas, $0.2 \mathrm{~L} / \mathrm{min}$; nebulizer, $0.8 \mathrm{~L} / \mathrm{min}$; sampling rate, $0.3 \mathrm{~mL} / \mathrm{min}$. Results were analyzed for statistical significance, which is shown in tabulated form as mean \pm SD, and ND indicating "not detectable." This research was performed in triplicate.

\section{Results and Discussion}

Twenty-two lipstick products purchased from a market in Jeddah were selected for analysis, twelve light- and ten dark-colored. An analytical estimation test was performed on fourteen elements in the lipsticks as summarized in (Table 4). The data presented in Table 4 reveal a marked difference from the data reported in the literature (Table 1). Comparing the results inside each class, it is clear that 
Table 3. Operational parameters of ICP/OES for the analyzed metal.

\begin{tabular}{|c|c|c|c|}
\hline heavy metals & gas mode & line & detection limit $/ \mu \mathrm{g} / \mathrm{g}$ \\
\hline $\mathrm{Al}$ & air \& $\mathrm{He}$ & 27 & 10.00 \\
\hline $\mathrm{Fe}$ & $\mathrm{He}$ & 56 & 10.00 \\
\hline $\mathrm{Ti}$ & air & 47 & 10.00 \\
\hline $\mathrm{Ag}$ & air & $107-109$ & 1.00 \\
\hline As & air \& $\mathrm{He}$ & 75 & 1.00 \\
\hline $\mathrm{Ba}$ & air & $135-137-138$ & 1.00 \\
\hline $\mathrm{Cd}$ & $\mathrm{He}$ & $111-113$ & 0.50 \\
\hline Co & air \& $\mathrm{He}$ & 59 & 1.00 \\
\hline $\mathrm{Cr}$ & air \& $\mathrm{He}$ & $52-53$ & 1.00 \\
\hline $\mathrm{Cu}$ & $\mathrm{He}$ & 63 & 1.00 \\
\hline $\mathrm{Mn}$ & $\mathrm{He}$ & 55 & 10.00 \\
\hline $\mathrm{Ni}$ & He \&air & 60 & 1.00 \\
\hline $\mathrm{Pb}$ & air & 105 & 1.00 \\
\hline $\mathrm{Zn}$ & $\mathrm{He}$ & 68 & 1.00 \\
\hline
\end{tabular}

Table 4. Total average concentration of toxic metals in light-colored (A, C) and darkcolored (B) lipstick samples and of different classes.

\begin{tabular}{|c|c|c|c|c|c|c|c|c|c|c|c|}
\hline \multirow{2}{*}{ 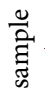 } & \multicolumn{7}{|c|}{ Low class } & \multicolumn{2}{|c|}{ Middle class } & \multicolumn{2}{|c|}{ High class } \\
\hline & 1 & 2 & 3 & 4 & 5 & 6 & 7 & 8 & 9 & 10 & 11 \\
\hline A & 4107.1 & 17594. & 2793 & 691394.941 & 1046.33 & 10506.44 & 15441.42 & 3475.1 & 5308.89 & 95747.12 & 6355.08 \\
\hline B & 32229.8 & 960800. & 264 & 774078.051 & 4288.57 & 9348.58 & 19481.613 & 30680.91 & - & 9361.91 & 3693.21 \\
\hline $\mathrm{C}$ & - & - & - & 1201.35 & - & - & - & - & - & - & - \\
\hline
\end{tabular}

the $\mathrm{Al}, \mathrm{Fe}, \mathrm{Ba}$, and $\mathrm{Zn}$ concentrations in the samples under examination are relatively higher than those of the other elements analyzed (Figure 1$)$. The $(n=22)$ average concentrations of heavy metals in the tested samples (22) were found equal $313.18 \pm 0.09 \mu \mathrm{g} / \mathrm{g}$ (range $201-11795 \mu \mathrm{g} / \mathrm{g}$ ), with the highest concentration in (3-A) whereas the lowest in (4-B) was noticed for Al; $9642.92 \pm 0.079$ $\mu \mathrm{g} / \mathrm{g}(69-59702 \mu \mathrm{g} / \mathrm{g})$. Regarding Fe, the highest concentration in (2-B) and minimum in (10-A) and the overall value was $46.59 \pm 0.109 \mu \mathrm{g} / \mathrm{g}(16-187 \mu \mathrm{g} / \mathrm{g})$. The highest concentration observed in (1-B) followed by the lowest concentration in (8-B) was noticed for Ti; $0.545 \pm 0.009 \mu \mathrm{g} / \mathrm{g}(1.08-3.5 \mu \mathrm{g} / \mathrm{g})$, while for $\mathrm{Ag}$ maximum concentration was observed in (10-B) and minimum in (11-A) 2.041 $\pm 0.024 \mu \mathrm{g} / \mathrm{g}(1.49-14.13 \mu \mathrm{g} / \mathrm{g})$. The highest concentration in (11-B) and lowest in $(10-\mathrm{B})$ for As; $1371.439 \pm 0.085 \mu \mathrm{g} / \mathrm{g}(97-5694 \mu \mathrm{g} / \mathrm{g})$. For $\mathrm{Ba}$, the highest concentration was noticed in (6-B) and lower concentration in (4-C) with an average $0.134 \pm 0.008 \mu \mathrm{g} / \mathrm{g}(0.66-0.86 \mu \mathrm{g} / \mathrm{g})$. In (4-C) maximum concentration was noticed whereas minimum in (11-A) for Cd; with an average of $4.242 \pm 0.02$ $\mu \mathrm{g} / \mathrm{g}(1.42-17.72 \mu \mathrm{g} / \mathrm{g})$. Highest concentration in (11-B) and the lower concen- 


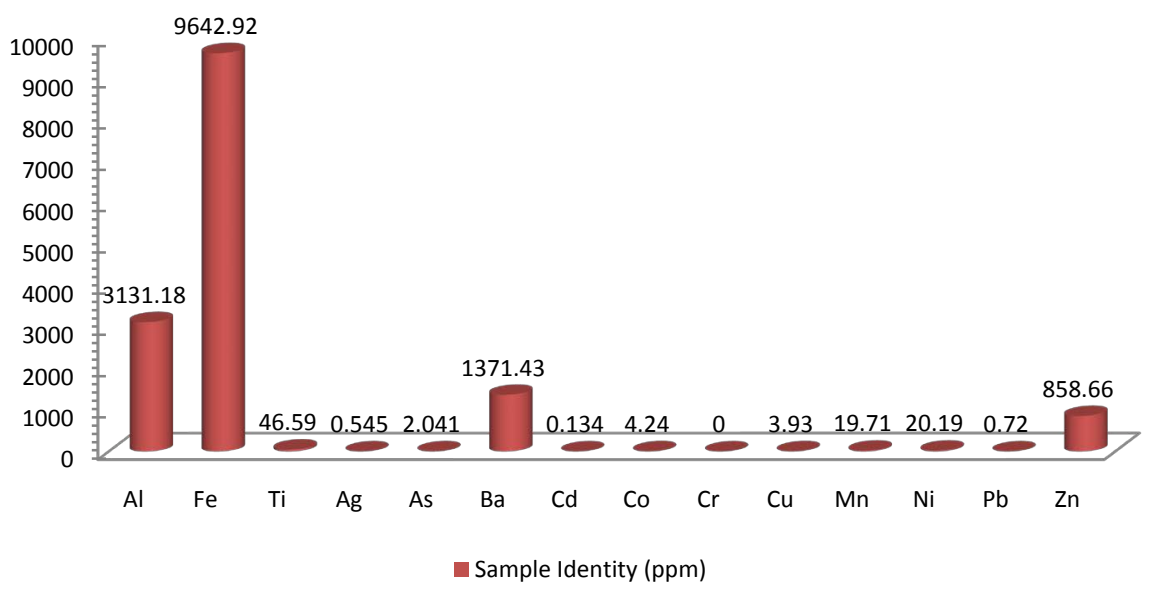

Figure 1. Comparative average concentrations of the tested heavy metals in the lipstick cosmetic products.

tration in (8-A) for Co with an average of $3.934 \pm 0.03 \mu \mathrm{g} / \mathrm{g}(1.07-19.09 \mu \mathrm{g} / \mathrm{g})$, whereas for $\mathrm{Cu}$ highest concentration was noticed in (1-A) and lowest in (10-B) with average of $19.712 \pm 0.012 \mu \mathrm{g} / \mathrm{g}(10-140 \mu \mathrm{g} / \mathrm{g})$. For $\mathrm{Mn}$, the highest concentration was noticed in (3-B) while the lowest in (11-A) with an average of 20.196 $\pm 0.056 \mu \mathrm{g} / \mathrm{g}(9.42-108.02 \mu \mathrm{g} / \mathrm{g})$. For $\mathrm{Ni}$, the highest concentration was observed in (3-B) and lowest in (2-A) with an average of $0.725 \pm 0.012 \mu \mathrm{g} / \mathrm{g}(3.15-8.22$ $\mu \mathrm{g} / \mathrm{g})$. The highest concentration in (8-A) and lowest in (10-B) for $\mathrm{Pb} ; 858.666 \pm$ $0.083 \mu \mathrm{g} / \mathrm{g}(498-1238 \mu \mathrm{g} / \mathrm{g})$ with the highest concentration for $\mathrm{Zn}$ in (1-A) and the lowest in (3-A) sample. In all samples, chromium was not detected.

The total concentrations of metals in different samples ranged from $1.20 \times 10^{3}$ to $6.08 \times 10^{4} \mu \mathrm{g} / \mathrm{g}$ (Table 4). Higher total metal concentrations were found in dark-colored samples and lower concentrations were found in light-colored samples, with the exception of samples 6,9 , and 11. Table 4 demonstrates that lipstick products assigned to the high class category have the lowest average total metal concentrations (11-B), ranging from 3693.21 up to (10-B) $9361.91 \mu \mathrm{g} / \mathrm{g}$, while the middle class has (8-A) 3475.1 to (8-B) $3068.91 \mu \mathrm{g} / \mathrm{g}$, and the highest average total metal concentrations are found in lower class lipsticks, from (4-C) 1201.35 up to (2B) $60800.36 \mu \mathrm{g} / \mathrm{g}$. This finding indicates that the higher class of lipsticks (more expensive, higher quality) is safer than the lower class (less expensive, lower quality), and is consistent with earlier research for lead and cadmium levels in various cosmetic brands [3]. The highest concentrations of the various elements detected were found in sample number 9 of the lower class brands, while the lowest level was in sample 8 of higher class brands (Table 5). Based on the average levels of heavy metal (Table 5), the samples can be arranged in the decreasing order: $\mathrm{Fe}>\mathrm{Al}>\mathrm{Ba}>\mathrm{Zn}>\mathrm{Ni}>\mathrm{Mn}>\mathrm{Ti}>\mathrm{Co}>\mathrm{Cu}>$ $\mathrm{As}>\mathrm{Pb}>\mathrm{Ag}>\mathrm{Cd}>\mathrm{Cr}$. Most products in this study were detected to contain high concentrations of heavy metals, particularly $\mathrm{Fe}, \mathrm{Al}, \mathrm{Ba}$, and $\mathrm{Zn}$, which showed a high degree of variation among the samples (Figure 1).

A comparison of the data of this study (Table 6) with the literature (Table 7) of other countries revealed that, the concentrations of heavy metals in the 
Table 5. Highest and lowest heavy metals content in the analyzed samples.

\begin{tabular}{ccccc}
\hline Element & Highest conc. $\mu \mathrm{g} / \mathrm{g}$ & Sample code & Lowest conc. $\mu \mathrm{g} / \mathrm{g}$ & Sample code \\
\hline $\mathrm{Al}$ & 11795 & $3-\mathrm{A}$ & 201 & $4-\mathrm{B}$ \\
$\mathrm{Fe}$ & 59702 & $2-\mathrm{B}$ & 69 & $10-\mathrm{A}$ \\
$\mathrm{Ti}$ & 187 & $1-\mathrm{B}$ & 16 & $8-\mathrm{B}$ \\
$\mathrm{Ag}$ & 3.50 & $10-\mathrm{B}$ & 1.08 & $11-\mathrm{A}$ \\
$\mathrm{As}$ & 14.13 & $11-\mathrm{B}$ & 1.49 & $10-\mathrm{B}$ \\
$\mathrm{Ba}$ & 5694 & $6-\mathrm{B}$ & 97 & $4-\mathrm{C}$ \\
$\mathrm{Cd}$ & 0.86 & $4-\mathrm{C}$ & 0.66 & $11-\mathrm{A}$ \\
$\mathrm{Co}$ & 17.72 & $11-\mathrm{B}$ & 1,42 & $8-\mathrm{A}$ \\
$\mathrm{Cr}$ & $\mathrm{ND}$ & - & $\mathrm{ND}$ & \\
$\mathrm{Cu}$ & 9.09 & $1-\mathrm{A}$ & 1.07 & $10-\mathrm{B}$ \\
$\mathrm{Mn}$ & 140 & $3-\mathrm{B}$ & 10 & $6-\mathrm{B}$ \\
$\mathrm{Ni}$ & 108.02 & $3-\mathrm{B}$ & 9.42 & $2-\mathrm{A}$ \\
$\mathrm{Pb}$ & 8.22 & $8-\mathrm{A}$ & 3.15 & $10-\mathrm{B}$ \\
$\mathrm{Zn}$ & 1238 & $1-\mathrm{A}$ & 498 & $3-\mathrm{A}$ \\
\hline
\end{tabular}

Table 6. Descriptive statistical summary of average concentrations (Average \pm SD) of heavy metals in various lipstick products in $\mu \mathrm{g} / \mathrm{g}^{\dagger}$.

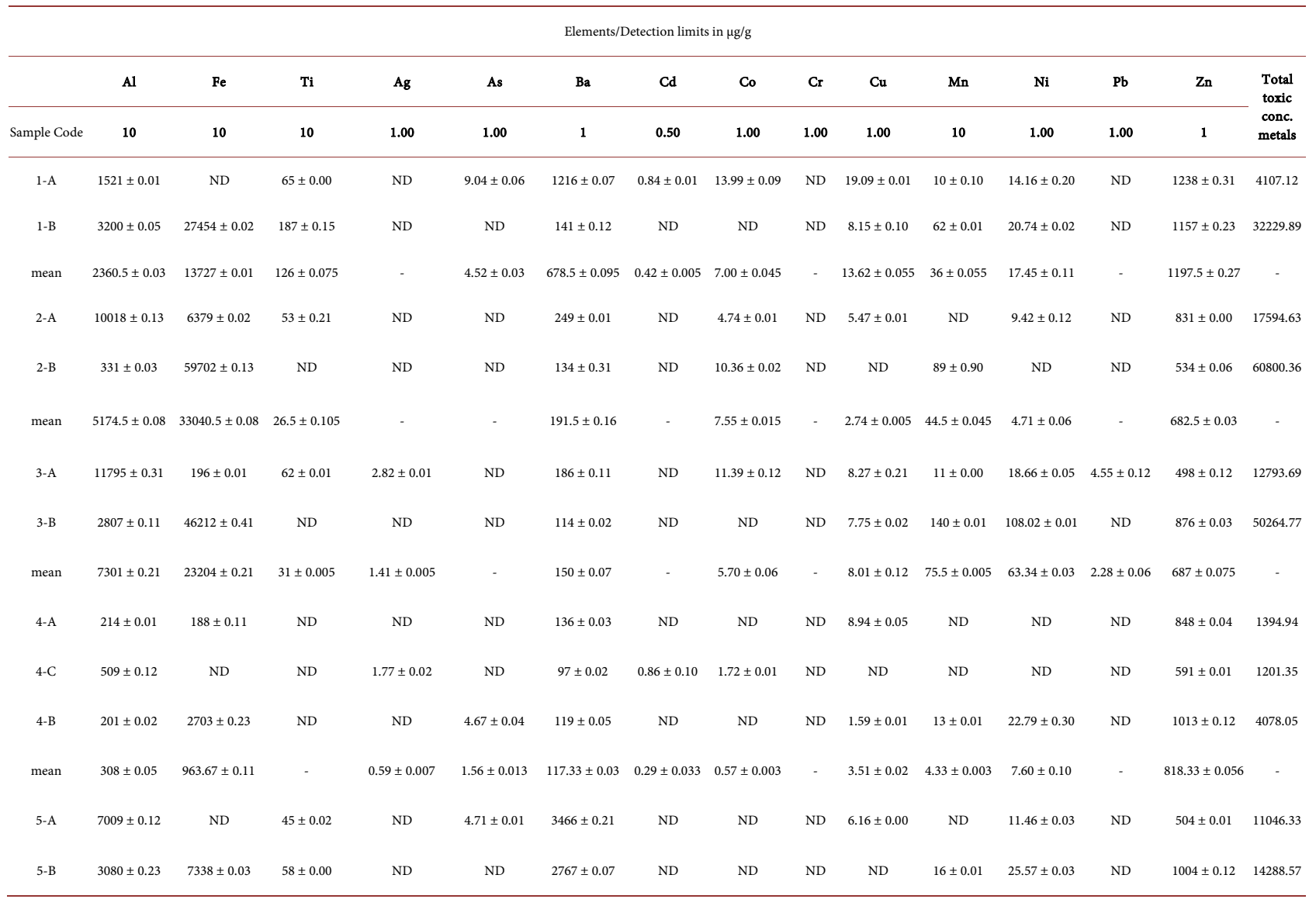




\section{Continued}

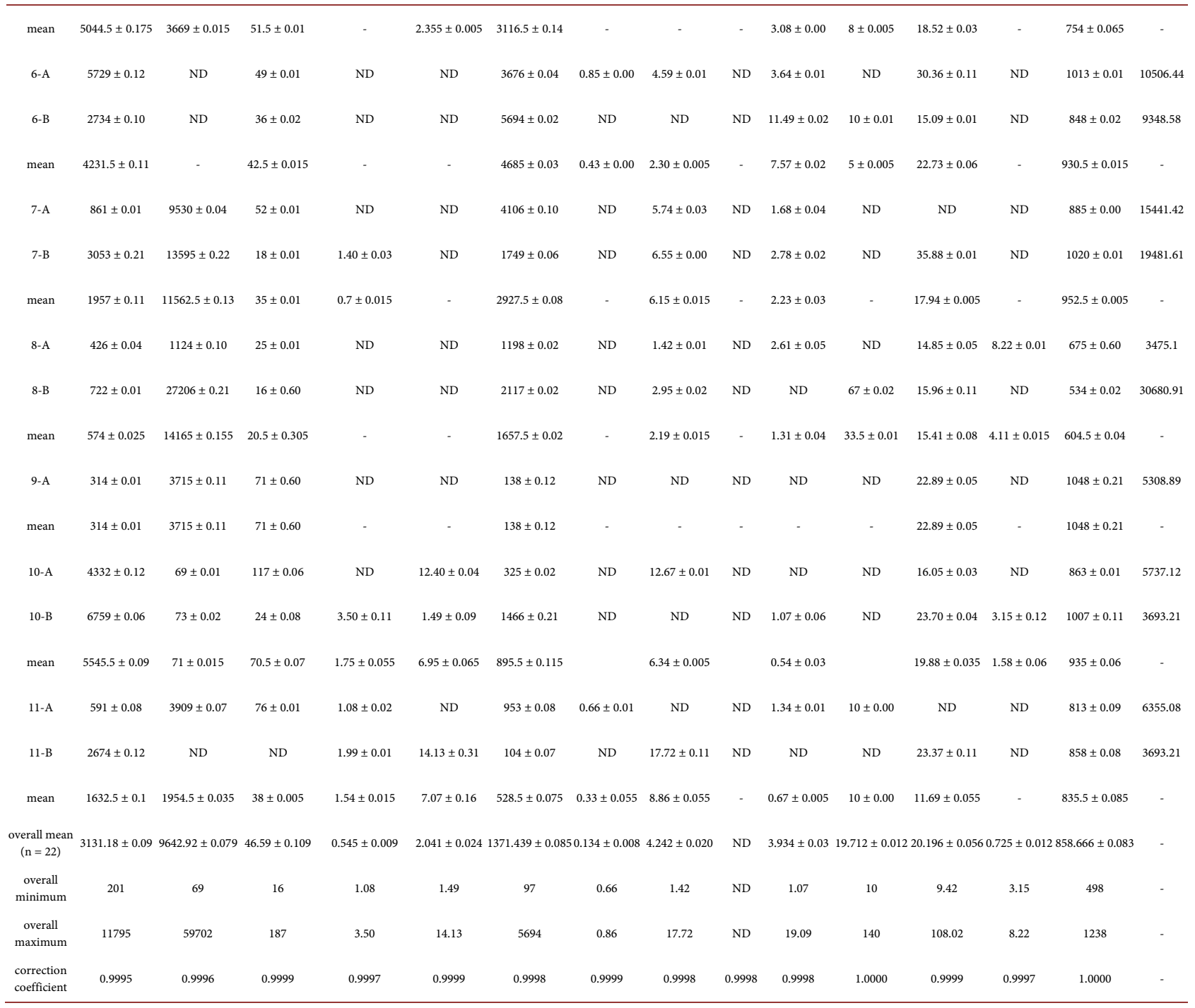

${ }^{\dagger}$ Average \pm Standard deviation $(\mathrm{SD})$; nd $=$ not determined.

cosmetic products are not reported for $\mathrm{Al}, \mathrm{Ti}, \mathrm{Ag}, \mathrm{As}, \mathrm{Ba}$, and $\mathrm{Mn}$ in six studies. $\mathrm{Al}$ is added to lipsticks as a stabilizer to keep colors from running, and to lip glosses, lipsticks, and nail polishes as a colorant. $\mathrm{TiO}_{2}$ is used as a whitening agent, for softening reds into pinks, and as an antioxidant, both of which uses are approved by the FDA; the SASO allows up to $25 \% \mathrm{TiO}_{2}$ in cosmetic products. In the present study, the levels of $\mathrm{Ti}$ (in the form of $\mathrm{TiO}_{2}$ ) was ranged between $0.0026 \%$ and $0.312 \%$.The highest concentration of Fe found $(59,702 \mu \mathrm{g} / \mathrm{g})$ was found to be higher than that reported for lipstick products [6] [10] [19] [20]. The high of Fe is most likely attributed to the established role of iron compounds as colorants in cosmetics. On the other hand, Ag and As were found as impurities. Barium is banned by the SASO, but it was detected at levels up to $5694 \mu \mathrm{g} / \mathrm{g}$ owing to its use as a colorant. Cadmium is banned in cosmetics because of its toxicity, to which children are particularly susceptible [17], while the 


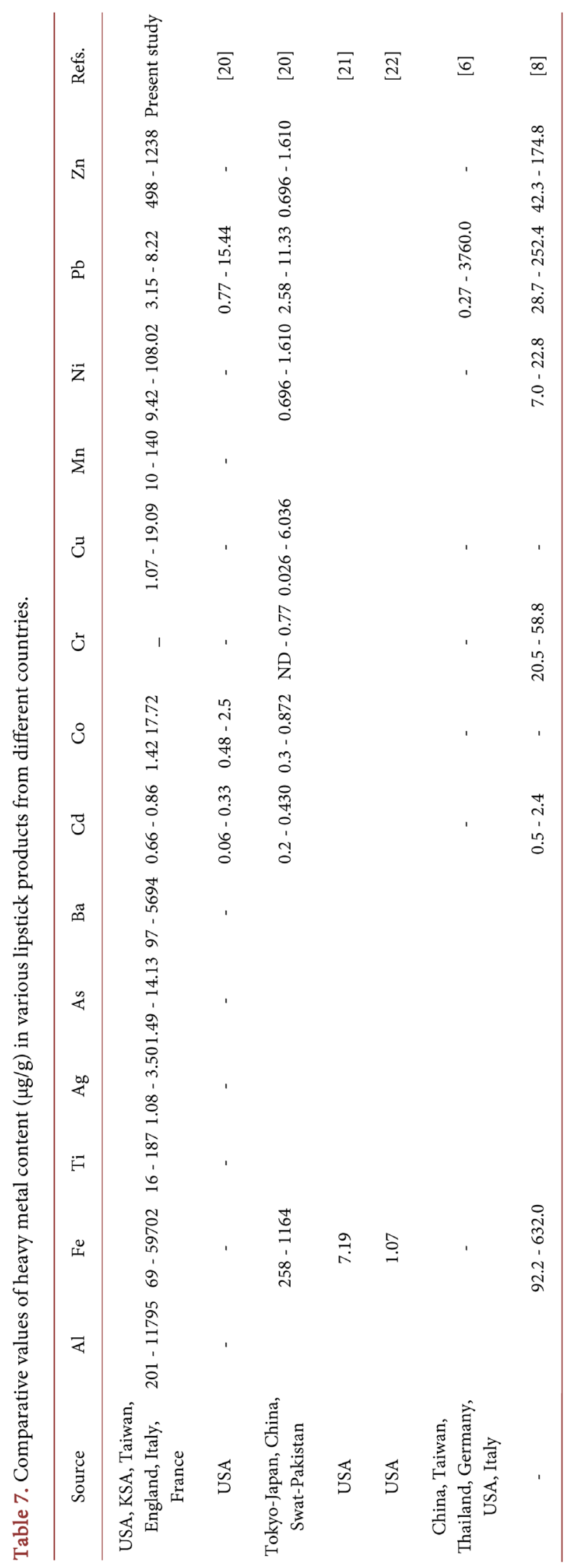


highest concentration of this element $(0.86 \mu \mathrm{g} / \mathrm{g})$ was found to be lower than the maximum value reported $(2.4 \mu \mathrm{g} / \mathrm{g})$ in literature [6]. Maximum concentration of Co $(17.72 \mu \mathrm{g} / \mathrm{g})$ was found higher than that reported in any study of cosmetic products. No Cr was detected in any product, though the detection limit was $1.00 \mu \mathrm{g} / \mathrm{g}$. Maximum value of $\mathrm{Cu}(19.09 \mu \mathrm{g} / \mathrm{g})$ was found to be higher than that reported in the most recent study (10). Levels of manganese, which is used as a catalyst for pigments and is not banned, were found up to $140 \mu \mathrm{g} / \mathrm{g}$. The maximum value for $\mathrm{Ni}(108.02 \mu \mathrm{g} / \mathrm{g})$ was found to be higher than that reported in most previous studies [6] [10]. The highest concentration of $\mathrm{Pb}(8.22 \mu \mathrm{g} / \mathrm{g})$ was found to be lower than the reported values [6] [9] [10] [18]. The maximum value of $\mathrm{Zn}(1238 \mu \mathrm{g} / \mathrm{g})$, which as an oxide has properties similar to $\mathrm{TiO}_{2}$, was found to be higher than any report in the literature. Heavy metals bind with proteins in cells, leading to cell death and multiple diseases [26]. These heavy metals in lipsticks are impurities, as reported [27]. The slow liberation of these metals into the body means that they may cause damage after accumulating over time in various organs [14] [28]. Other studies have also reported heavy metal concentrations in various cosmetic products [2].

\section{Conclusion}

The levels of 14 heavy metals including $\mathrm{Al}$ and $\mathrm{Ba}$ in lipstick products imported from different countries and from the local market in Jeddah, Saudi Arabia are reported. Only three of the samples contained low levels of $\mathrm{Pb}$, and 4 samples showed very low levels of Cd; 6 samples had low levels of As, while all samples contained Baat various levels. The latter metals were banned by the SASO, making all of the products that contain them contraband. High levels of $\mathrm{Fe}$ and $\mathrm{Al}$ were noticed in most lipstick products. The light-colored lipsticks appear to be safer than the dark-colored ones in terms of metal concentrations. Continued use of such cosmetics products containing heavy metals may result in the slow liberation of these metals into the human body, which in turn causes harmful effects. Based on these findings, extensive uses of such products should be avoided. Thus, there is need for further assessment of risk to human health from exposure to cosmetics that are contaminated with heavy metals. Careful selection of the raw materials used in producing them with regard to heavy metal content can improve the safety of cosmetics and their impact on the environment.

\section{References}

[1] Brown, V.J. (2013) Metals in Lip Products-A Cause for Concern? Environmental Health Perspectives, 121, 196. https://doi.org/10.1289/ehp.121-a196

[2] Al-Dayel, O., Hefne, J. and Al-Ajyan, T. (2011) Human Exposure to Heavy Metals from Cosmetics. Oriental Journal of Chemistry, 27, 1-11.

[3] Chauhan, A.S., Bhadauria, R., Sing, A.K., Lodhi, S.S., Chaturvedi, D.K. and Tomar, V.S. (2010) Determination of Lead and Cadmium in Cosmetic Products. Journal of Chemical Pharmacology Research, 2, 92-97. 
[4] Sainio, E.L., Jolanki, R., Hakala, E. and Kaerva, L. (2000) Metals and Arsenic in Eye Shadows. Contact Dermatitis, 42, 5-10. https://doi.org/10.1034/j.1600-0536.2000.042001005.x

[5] Volpe, M., Nazzaro, M., Coppola, R., Rapuano, F. and Aquino, R.P. (2012) Determination and Assessments of Selected Heavy Metals in Eye Shadow Cosmetics from China, Italy, and USA. Microchemical Journal, 101, 65-69. https://doi.org/10.1016/j.microc.2011.10.008

[6] Al-Saleh, I., Al-Enazi, S. and Shinwari, N. (2009) Assessment of Lead in Cosmetic Products. Regulatory Toxicology and Pharmacology, 54, 105-113. https://doi.org/10.1016/j.yrtph.2009.02.005

[7] Grosser, Z., Davidowski, L. and Thompson, L. (2011) The Determination of Metals in Cosmetics. Perkin Elmer Application Note, 1-6.

[8] Nnorom, I., Igwe, J. and Oji-Nnorom, C. (2005) Trace Metal Contents of Facial (Make-Up) Cosmetics Commonly Used in Nigeria. African Journal of Biotechnology, 4, 1133-1138.

[9] Saeed, M., Muhammad, N. and Khan, H. (2010) Analysis of Toxic Heavy Metals in Branded Pakistani Herbal Products. Journal of the Chemical Society of Pakistan, 32, 471-475.

[10] Barakat, M. (2011) New Trends in Removing Heavy Metals from Industrial Wastewater. Arabian Journal of Chemistry, 4, 361-377. https://doi.org/10.1016/j.arabjc.2010.07.019

[11] Flora, S.J. and Pachauri, V. (2010) Chelation in Metal Intoxication. International Journal of Environmental Research and Public Health, 7, 2745-2788. https://doi.org/10.3390/ijerph7072745

[12] Second National Report on Human Exposure to Environmental Chemicals (2003) US Department of Health and Human Services, Centers for Disease Control and Prevention. National Center for Environmental Health, Atlanta, GA.

[13] Theresa, O.C., Dorcas, W.A. and Ajani, O.I. (2011) Potentially Toxic Metals Exposure from Body Creams Sold in Lagos, Nigeria. Researcher, 3, 30-37.

[14] Ayenimo, J., Yusuf, A.M., Adekunle, A.S. and Makinde, O.W. (2010) Heavy Metal Exposure from Personal Care Products. Bulletin of Environmental Contamination and Toxicology, 84, 8-14. https://doi.org/10.1007/s00128-009-9867-5

[15] Patel, P. (2016) Toxic Cosmetics: Lead in Lipstick. Bioclinic Naturals.

[16] Muhammad, D. and Farurtwa, S.P.B. (2014) Study of Heavy Metals Content in Facial Cosmetics Obtained from Open Markets and Superstores within Kaduna metropolis, Nigeria. American Journal of Chemistry and Application, 1, 27-33.

[17] Basketter, D.A., Angelini, G., Ingber, A., Kern, P.S. and Menné, T. (2003) Nickel, Chromium and Cobalt in Consumer Products: Revisiting Safe Levels in the New Millennium. Contact Dermatitis, 49, 1-7. https://doi.org/10.1111/j.0105-1873.2003.00149.x

[18] Bocca, B., Forte, G., Petrucci, F. and Cristaudo, A. (2007) Levels of Nickel and Other Potentially Allergenic Metals in Ni-Tested Commercial Body Creams. Journal of Pharmaceutical and Biomedical Analysis, 44, 1197-1202. https://doi.org/10.1016/j.jpba.2007.04.031

[19] Saudi Standards, Metrology and Quality Organization (2005) Cosmetic Products-The Cosmetic Products (Safety) Regulations 1953. SASO, Riyadah.

[20] Zakaria, A. and Ho, Y.B. (2015) Heavy Metals Contamination in Lipsticks and Their Associated Health Risks to Lipstick Consumers. Regulatory Toxicology and Phar- 
macology, 73, 191-195. https://doi.org/10.1016/j.yrtph.2015.07.005

[21] Hepp, N.M. (2011) Determination of Total Lead in 400 Lipsticks on the US Market using a Validated Microwave-Assisted Digestion, Inductively Coupled Plasma-Mass Spectrometric Method. Journal of Cosmetic Science, 63, 159-176.

[22] Hepp, N.M., Mindak, W.R. and Cheng, J. (2009) Determination of Total Lead in Lipstick: Development and Validation of a Microwave-Assisted Digestion, Inductively Coupled Plasma-Mass Spectrometric Method. Journal of Cosmetic Science, 60, 405-414.

[23] Zakir, S.N., Ihsanullah, I., Shah, M.T. and Iqbal, Z. (2009) Determination of Major and Trace Elements in Soil of Peshawar Basin. Journal of the Chemical Society of Pakistan, 31, 246-256.

[24] Liu, H., Chen, L.P., Ai, Y.W., Yang, X., Yu, Y.H., Zuo, Y.B. and Fu, G.Y. (2009) Heavy Metal Contamination in Soil alongside Mountain Railway in Sichuan, China. Environmental Monitoring and Assessment, 152, 25-33. https://doi.org/10.1007/s10661-008-0293-7

[25] Parry, C. and Eaton, J. (1991) Kohl: A Lead-Hazardous Eye Makeup from the Third World to the First World. Environmental Health Perspectives, 94, 121-123. https://doi.org/10.2307/3431304

[26] Shanker, A.K. (2008) Mode of Action and Toxicity of Trace Elements. In: Prasad, M.N.V., Ed., Trace Elements as Contaminants and Nutrients: Consequences in Ecosystems and Human Health, Chapter 21, John Wiley \& Sons, Inc., Hoboken. https://doi.org/10.1002/9780470370124.ch21

[27] (2011) The Health Risks of Hidden Heavy Metals in Face Makeup. Environmental Defence, Toronto. http://www.ottawacitizen.com/pdf/HeavyMetalHazard.pdf

[28] Adepoju-Bello, A.A., Oguntibeju, O.O., Adebisi, R.A., Okpala, N. and Coker, H.A. (2012) Evaluation of the Concentration of Toxic Metals in Cosmetic Products in Nigeria. African Journal of Biotechnology, 11, 16360-16364. 